\title{
The introduction of chlorpromazine in Belgium and the Netherlands (1951-1968); tango between old and new treatment features
}

\author{
Toine Pieters ${ }^{\mathrm{a}, \mathrm{b}}$, Benoît Majerus ${ }^{\mathrm{c}}$ \\ ${ }^{a}$ Descartes Centre for the History and Philosophy of the Sciences and the Humanities/Department of Pharmaceutical Sciences, University of Utrecht, The Netherlands \\ ${ }^{\mathrm{b}}$ Department of Medical Humanities, VU Amsterdam Medical Centre, The Netherlands \\ ' Université du Luxembourg, Unité de Recherche IPSE (Identités, Politiques, Sociétés, Espaces), Luxembourg
}

\section{A R T I C L E I N F O}

\section{Article history:}

Available online 22 June 2011

\section{Keywords:}

Therapeutic drugs

Standardization

Pharmaceutical industry

Thorazine/Largactil/Megaphen

(chlorpromazine)

Psychiatry

History of pharmacy

Medical history

\begin{abstract}
A B S T R A C T
The introduction of chlorpromazine in Belgium and the Netherlands demonstrates an intriguing tango between old and new treatments. Chlorpromazine, marketed by the French company Rhône Poulenc entered psychiatry as an adjunct to existing therapies. Instead of promoting chlorpromazine as a revolutionary therapy, we see early efforts to market Largactil as a supplement to the armoury of psychiatric treatments. These marketing efforts matched the idiosyncrasies of national and local styles and cultures. Despite continuities with earlier therapeutic developments, we support the notion of a therapeutic revolution. In the early sixties supply and demand provoked a turn towards more standardized therapeutic regimes.
\end{abstract}

(c) 2011 Elsevier Ltd. All rights reserved.

When citing this paper, please use the full journal title Studies in History and Philosophy of Biological and Biomedical Sciences

\section{Introduction}

Historians generally agree that the introduction of chlorpromazine, in 1952, marketed either as Thorazine ${ }^{\circledR}$, Largactil ${ }^{\circledR}$ or Megaphen ${ }^{\circledR}$, marked the start of a new era of drug treatment in psychiatry. ${ }^{1}$ The concept of a therapeutic revolution, however, is a contested notion as historical evidence points to continuity with earlier therapeutic developments in psychiatry. This study explains the various ways in which chlorpromazine's scientific, medical and cultural profile was established as part of a dynamic health care landscape in two neighbouring countries, Belgium and the Netherlands. This implies accounting for the possible role of chlorpromazine in redrawing the map of diagnostic and therapeutic regimes in Belgian and Dutch psychiatric practice-as a prototype of a specific class of modern day drugs, antipsychotics. In our paper we will argue that the introduction and use of chlorpromazine demonstrates an intriguing tango between old and new treatment features. Histori- cally, as a consequence of national and local practices and cultures, scientists, doctors, nurses, patients and marketers attributed new features, meanings and identities to chlorpromazine.

Chlorpromazine, pragmatically marketed in Europe by the French chemical company, Rhône Poulenc, entered Belgian and Dutch psychiatry as an ad hoc adjunct to existing psychotropic drug therapies and other bodily cures. Instead of promoting chlorpromazine as a revolutionary therapy, we see early efforts to promote Largactil as a supplement to the existing armoury of psychiatric treatments. We will show how these marketing efforts matched the idiosyncrasies of national and local styles and cultures for healing the mind. New therapeutic and diagnostic categories and the so-categorized patients emerged hand in hand and changed as material and social conditions changed. Doctors, nurses, patients, scientists and marketers had to learn to use, cope with and communicate with each other about a new generation of psychotropics in laboratory, clinic and household settings; redefining

\footnotetext{
E-mail addresses: t.pieters@uu.nl, a.pieters@vumc.nl (T. Pieters), benoit.majerus@uni.lu (B. Majerus)

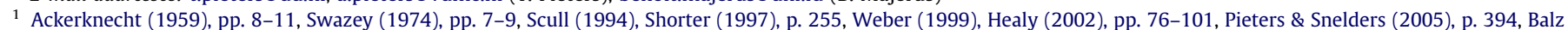
(2010) pp. 29-33.
} 
the boundaries between: therapeutic effects and side effects, laboratory and clinical measures, and hospital care and outpatient care.

As part of this process of coping with and communicating, drug standards (as a means of managing the various options for psychiatric treatment) had differing value for scientists, doctors, patients and companies in the 1950s and 1960s. In the 1950s, drug standards were important only in terms of in-house production and safety standards for the pharmaceutical industry. Standards for psychotropic prescription practices ran counter to the established flexible practice of the materia medica with a strong focus on individually tailored drug therapies. ${ }^{2}$ It was believed that promoting drug standards would harm commercial standards by alienating doctors. Not until the sixties did the dynamics of supply and demand in psychiatry provoke a turn towards more standardized therapeutic regimes. Issues of governance and control, as we will show, played a significant role in this respect.

\section{4560 RP on probation: shaking cocktails}

The French chemical multinational, Rhône-Poulenc, through its international pharmaceutical division, Specia, distributed the first samples of chlorpromazine under the research label $4560 \mathrm{RP}$ (code number corresponding to the laboratory synthesis book followed by the initials for Rhône Poulenc) for clinical investigative use-in order to determine the range of therapeutic uses and the tolerance-toxicity doses-first to medical investigators in France and subsequently abroad during the course of $1951 .^{3}$ Most common at the time was a so-called 'open' experiment in which the clinical researcher was held responsible for administering the pharmaceutical substance to volunteers or patients and monitoring their condition. There were no ethical committees to sanction (or otherwise) experiments on humans or formal rules on how to conduct a clinical trial. Control over testing new pharmaceutical substances was left to the good sense of the doctors and the pharmaceutical company involved. Based on patient records, the clinical investigator would form impressions of the potential toxicity-and the probable therapeutic value of the substance-and send a summary of the experiment with a conclusion to the trial sponsor. ${ }^{4}$

One of the protagonists in the development of chlorpromazine, the French surgeon Henry Laborit, was first to recognize the wider clinical potential of the experimental phenothiazine drug, 4560 RP. Together with his close companion, the anaesthetist Pierre Huguenard, Laborit pursued the idea of achieving anaesthesia with the lowest possible dose of the rather risky anaesthetic agents, by using preoperative medicinal cocktails to potentiate the anaesthetics. ${ }^{5}$ In the surgery department of Val de Grâce Military-Hospital in Paris, Laborit suggested a combination formulae and Huguenard prepared increasingly powerful preoperative cocktails. In the process they observed that cocktails containing hypnotics, analgesics, curare and a stabilizing antihistamine (e.g. the phenothiazine compound promethazine) put a body to rest to such an extent that metabolism was reduced to a minimum and the patient's temperature dropped significantly to 33-35 degrees Celsius, like a hibernating animal. Patients treated with these so-called 'lytic cocktails', part of a new procedure of so-called 'artificial hibernation', appeared to be resistant to operative shock and had an improved recovery from major surgical interventions. The experimental promethazine-like compound 4560 RP (with an additional chlorine atom) was also tested as a stabilizer in Laborit's and Huguenard's lytic cocktails. Adding chlorpromazine to the cocktails turned out to be remarkably effective as a component of artificial hibernation. Furthermore, the new phenothiazine drug not only seemed to potentiate hypnotics and sedatives, like the barbiturates, but also potentiated analgesics and had an anti-emetic effect. Moreover, chlorpromazine seemed to induce a distinct indifference in stressful pre-surgery patients. Because of the remarkable wide range of effects or chlorpromazine's 'large action', Laborit renamed $4560 \mathrm{RP}$ with the enthousiastic term-'Largactil'. The effects were striking enough to informally share with other hospital colleagues, such as the psychiatrist Pierre Hamon who was struggling, on a daily basis, to treat patients under stress with medication cocktails as a component of sleep therapy. Chlorpromazine's potentiating capacities would permit the use of a lower dose of hypnotics and sedatives with an improved margin of safety. The first trial of chlorpromazine in psychiatry, as in surgery, was a combination treatment in a medication cocktail. ${ }^{6}$

Throughout 1952, early communications on chlorpromazine's stabilizing and potentiating capacities in the field of surgery, and subsequently in psychiatry, were published in the renowned French medical journals La Presse Medicale and Annales MédicoPsychologiques, and circulated in France and abroad. ${ }^{7,8}$ Written reports on the testing for the experimental drug, $4560 \mathrm{RP}$, from well-established psychiatrists, Jean Delay and Pierre Deniker of the Sainte Anne Hospital in Paris, should have carried considerable weight. Nevertheless, the Belgian and Dutch response was to wait and see. Deniker's presentation at the 50th Congress of the French Society for Psychiatry and Neurology in Luxembourg at the end of July 1952 is exemplary as just a handful of colleagues attended the presentation. $^{9}$

A growing number of Dutch and Belgian physicians only began to take notice of the new drug in November 1952, as the drug was marketed in prescription form as Largactil ${ }^{\circledR}$. Historically, it was individual contacts between Specia sales representatives and psychiatrists that proved to be the major impetus to move chlorpromazine into Belgian and Dutch psychiatry. The marketing campaign surrounding Largactil's introduction was modest, even by early 1950s standards. Phenergan ${ }^{\circledR}$ (promazine) and Antallergan ${ }^{\circledR}$ (mepyraminum), antihistamines for general practice, as well as the hypnotic Soneryl ${ }^{\circledR}$ (butobarbital) were initially regarded as far more interesting commercially and received the majority of the marketing attention. ${ }^{10}$

The first marketing news for the novel drug Largactil ('large action') appeared in the stylish Specia marketing bulletin Médecine du France sent to medical specialists with a track-record of prescribing Specia drugs in Belgium and the Netherlands, among other European countries. ${ }^{11}$ Largactil (4560 RP) was presented as a new nervous system modifier, a so-called 'neuroplegicum', with a remarkable broad range of pharmacological effects and potential broad therapeutic spectrum. However promising as a remedy for all kinds of nervous system related symptoms and ills (e.g., pruritis, nausea, and anxiety) the Largactil marketing focus was initially as a narcotic, hypnotic, sedative and analgesic potentiator: positioning Largactil as an adjunct to existing medication practices in surgery,

\footnotetext{
2 Kraft TB, personal 1950s prescription booklet; series of interviews in preparation of the Amsterdam psychotropic drug witness seminar, 08-06-2001.

3 Swazey (1974), pp. 96-97.

4 Pieters (2005), p. 58.

5 Thuillier (1999), pp.104-105.

${ }^{6}$ Thuillier (1999), pp. 107-109, Healy (2002), pp. 81-82.

7 Laborit, Huguenard, \& Alluaume (1952), pp. 206-208, Deschamps (1952)pp. 944-946.

8 Delay, Deniker, \& Harl (1952a), Delay, Deniker, \& Harl (1952b), Hamon, Paraire, \& Velluz (1952).

9 Swazey (1974), p. 134.

10 Interviews with Dutch and Belgian 1950s Specia sales representatives; D. Cannoo, Leiden, 7-9-2000; F. Busser, Breskens, 10-9-2000; J. van den Bergh, Antwerpen, 27-10-2000.

11 Médecine de France, No XXXVIII (1952), supplementary sheet.
} 
obstetrics and in psychiatry. ${ }^{12}$ Subsequently, the marketing message in Belgian and Dutch medical journals was that Largactil would self-evidently find its proper place in medical practice, in terms of indications and uses (e.g. dosage and forms), 'in the service' of the surgeon, obstetrician or psychiatrist. ${ }^{13}$ Doctors were, so to speak, invited to pioneer the therapeutic profile of Largactil.

\section{4560 RP on trial in Dutch and Belgian psychiatry}

The first to act on the news in the Netherlands, was Piet Teenstra, the director and psychiatrist of the Dutch asylum, Duinenbosch. Teenstra regularly read French medical journals and maintained close contact with a scientific staff member of Barberot Specia, the Dutch sales department of Specia. ${ }^{14}$ The company's showpiece was the powerful antihistamine drug, Phenergan ${ }^{\circledR}$, used for the treatment of allergies, hypothermia, wounds and stress reactions. Due to its sedative properties, Phenergan had been successfully used as a component in sedative drug cocktails for prolonged sleep therapy. This form of physical therapy involved maintaining unruly and psychotic patients in a continuous sleep for several days or even weeks; the rational was to give the nervous system a rest and thereby, a chance to stabilize. Sleep therapy was practised in Dutch asylum psychiatry on a regular basis from the 1930s onwards. ${ }^{15}$

Teenstra wanted to test the potentiating effects of this new and supposedly more powerful experimental $4560 \mathrm{RP}$ compound as it was closely related to the well-known antihistamine and sedative Phenergan. He asked Specia for a supply of the still experimental drug, and obtained it overnight. To the surprise of an inexperienced young female physician, Nelly-Mary van de Wardt-Kikkert, she was assigned to test $4560 \mathrm{RP}$ (chlorpromazine) as part of a prolonged sleep therapy on the most unruly case in the female 'chronic disturbance' pavilion. The first Dutch woman to serve as a research subject was a thirty-two-year-old schizophrenic, who suffered from hallucinations, voices and insane ideas and had sunk into an inaccessible aggressive psychotic state. She was so unruly that she was kept in almost permanent solitary confinement and straight-jacketed as a means of coercion. Sedation, insulin coma therapy, and electroshock therapy had all failed to have an effect on her condition. In a final effort to prevent a 'last-ditch' surgical leucotomy she was placed at the top of the trial list for an extrastrong sleep therapy. Due to a shortage of nurses, however, doctor Van de Wardt-Kikkert decided not to follow the usual sleep therapy protocol, which required careful patient monitoring over several days and even weeks in order to prevent serious breathing problems. She decided to skip the narcotic component of the sleep therapy cocktail and test a mono-therapy of chlorpromazine. ${ }^{16}$

Chlorpromazine was given twice daily by intramuscular injections in 50-milligram doses. The patient had to be kept in a prone position for several hours after each injection to avoid problems with falling due to a sudden decrease in blood pressure. The initial therapeutic response was remarkable by any standard. The patient's behaviour improved significantly and she also appeared to wake up. Over several days she emerged from her psychotic state and was open to communication. Thereafter she progressed so rapidly that the staff allowed her to participate in the daily asylum routines and even put her in charge of the female pavilion. Unfortunately, the patient's progress halted immediately after the injections were discontinued due to a late arrival of a new batch of 4560 RP. Furthermore, the injections caused phlebitis in the patient and had to be diluted. Despite the reversible nature of the therapeutic effect and the rather painful injections, the overall evaluation was positive. Teenstra decided to scale up clinical testing as soon as $4560 \mathrm{RP}$ was introduced on the Dutch market under the trade name, Largactil. In the spring of 1953, a tablet and suppository form of the drug became available. ${ }^{17}$

The medical staff of the Dutch Duinenbosch asylum started administering chlorpromazine in a growing number of female and male patients who had been unresponsive to other forms of therapy, regardless of their diagnosis. Although considered to be a sedative, chlorpromazine appeared to sedate patients in an unusual way. Did chlorpromazine actually deliver an improved sleep therapy or was there more to it? Sedatives usually put patients to sleep or cause a lethargic drowsiness but in this case, chlorpromazine appeared to have a different action. After a couple of days of drowsiness, chlorpromazine produced a strange but therapeutic form of detachment. The resulting drop in patient noise levels was apparent to all professionals working and living in or near the asylum. Patients on a chlorpromazine drug regimen behaved as patients who were lobotomized. In accordance with her French and Belgian colleagues, Van de Wardt-Kikkert called this detachment a kind of 'pharmacological lobotomy'. ${ }^{18}$ But there was more to report on chlorpromazine than just the 'lobotomy' analogy. ${ }^{19}$ It was spectacular that some patients, who had been hospitalised for several years with chronic psychiatric conditions, opened up for communication and were receptive to social therapy ('actieve therapie'). ${ }^{20}$ On the basis of this successful early trial, the prescription rate of chlorpromazine at the Duinenbosch and neighbouring asylums would rise exponentially in the course of 1954 and $1955 .^{21}$ But Van de Wardt-Kikkert also issued an early warning statement about the emerging social-psychiatric problem of chronic patients, particularly women, as they returned to their families after years of absence, which put a serious burden on their recovery process. ${ }^{22}$

Frederik Tolsma, a psychiatrist and director of the psychiatric institution, Maasoord, on the outskirts of Rotterdam, reported similar test experiences. Tolsma was also familiar with the sedative qualities of the closely related drug Phenergan (promethazine) as a useful co-medication in sleep therapy. He had high expectations for the more potent fenothiazine analogue chlorpromazine and started experiments with free samples provided by a Specia sales representative in the summer of 1953. Unlike Teenstra, Tolsma's idea was to reproduce the French artificial hibernation and stabilize patients' nervous systems by combining chlorpromazine with artificial cooling of the body. Given the lack of expertise for the complex cooling procedure Tolsma, who wanted his institution

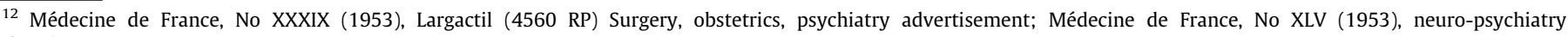
advertisement.

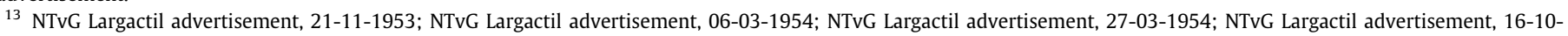
1954; Majerus (2010) p. 59.

14 Interview with Mrs. N. M. Van de Wardt-Kikkert, 15-12-2003; Interview with D. J. Cannoo, representative of the scientific department of Specia, 7 September 2000.

15 Schim van der Loeff \& Barnhoorn (1947), p. 396, Hamer \& Tolsma (1956), pp. 562-563.

16 Wardt-Kikkert van de \& Rentmeester (1953), p. 501; Interview with N. van de Wardt-Kikkert, 13 December 2003, Haarlem.

17 Ibid.

18 J. Delay (Ed.) (1956).

19 At this point in time the term 'pharmacological or fysiological leucotomy' did not have a negative connotation but rather a therapeutic one.

20 Wardt-Kikkert van de \& Rentmeester (1953)pp. 504, 505.

21 Psychische en medicamenteuze behandelingsmethoden. Supplementen bij Verslagen der Provinciale Ziekenhuizen van Noord-Holland over de jaren 1954 en 1955

22 Wardt-Kikkert van de (1956).
} 
to be a centre of excellence, reluctantly decided to administer chlorpromazine as part of conventional sleep therapy. ${ }^{23}$ Tolsma's team of researchers administered chlorpromazine, first as a constituent of a medication cocktail, but subsequently, also independently. A total of 70 chronic psychiatric patients with serious forms of restless and agitated behaviour were treated: 59 female and 11 men. In 53 cases a significant therapeutic effect was observed. Exemplary for the uncontrolled status of the trial is the following case report on the therapeutic effect in a female patient:

A forty-year-old woman was admitted in 1950 . She was very aggressive, restless and impetuous (...) She could hardly be maintained as part of the wheelbarrow squad. She was initially given chlorpromazine by intra-muscular injection (daily dose of $150 \mathrm{mg}$ ) followed by an oral regimen of 2 tablets three times a day (daily dose of $150 \mathrm{mg}$ ). Currently she is very calm. She has opened up for communication. She works on a regular basis in the laundry. ${ }^{24}$

One of the nurses working at the 'chronic unrest' pavilion noted that within a period of about six weeks after the introduction of chlorpromazine the unpleasant and aggressive atmosphere changed into a quiet and peaceful sanatorium. By effectively calming the most agitated and unruly patients, 'the terror cases of the institution', chlorpromazine was reported to significantly reduce the overall consumption of hypnotics and sedatives at the institution. ${ }^{25}$ Thus the chlorpromazine treatment group inadvertently had a therapeutically beneficial effect on the non-treatment group of patients.

However positive in its clinical assessment, Tolsma's research group did contribute some critical remarks. Chlorpromazine did not have a lasting therapeutic effect. In most cases the disease symptoms returned as soon as the patients stopped using the medication. Apparently a maintenance dosage was required, but it was far from clear whether the medication should be maintained for an indefinite period and what amount sufficed to control symptoms. Despite the fact that no 'consistently serious' problems were noted from the use of the drug, the medical staff observed unwelcome side effects. In addition to allergic reactions, problematic distortions in blood values and sudden drops in blood pressure were reported. Despite the warning by Tolsma's group that Largactil should be handled with caution, ${ }^{26}$ the message of promise and hope prevailed in the early Dutch and Belgian reports on the psychiatric use of chlorpromazine. ${ }^{27}$

Belgian physicians who first used chlorpromazine did so generally on their own initiative, as in the Netherlands, and requested information and free drug samples from Specia Rhône Poulenc after they learned of its therapeutic effects in the French medical press. However, Specia did not organize clinical trials by selected high-profile investigators to study specific actions of the drug in humans. During the course of 1953 and 1954 a couple of smallscale ad hoc trials were performed across Belgium. The Brothers of Charity, who were in charge of the majority of mental hospitals in Belgium, were the first to test $4560 \mathrm{RP}$ on psychiatric patients. In October 1953 one of the friars reported on the use of this new sedative to treat psychotic patients. The dosage range $(50-125 \mathrm{mg} /$ day) was the same used in the early Dutch trials. And in comparing the therapeutic effects with insulin coma therapy the ordeal was rather negative: 'At first glance a largactil treatment is not as impressive as the insulin treatment'. ${ }^{28}$ In line with the Rotterdam group, serious attention was given to side effects and recommendations made to closely monitor temperature and blood pressure, as well as the use of gloves by caregivers who distributed the tablets in order to prevent skin problems. In subsequent reports significant changes due to the use of chlorpromazine on the ward were reported. 'In effectively calming the most agitated and unruly patients [...] the largactil treatment will change the atmosphere of the chronic unrest departments.' Most in agreement with the Dutch reports was a more systematic study by the medical director of one of the major hospitals in Zelzate, physician Raf Jacobs, who treated a group of patients with chronic psychosis and another group with acute psychoses. His findings were positive for both groups: 'In a pavilion of troubled patients (...) [the largactil treatment] creates a serene atmosphere of calm and tranquility. For the more acute treatable psychoses, the largactil treatment is a precious, fast-acting and easy tool. ${ }^{29}$ He stressed that Largactil could be applied to a wide range of patients and that the name-Largactil or 'large action' of 'broad' and 'activity'-could be considered as justified. As his Dutch counterparts had done, Jacobs used the leucotomy analogy to characterize the therapeutic effect. However, his promising account did not necessarily mean that chlorpromazine was adopted overnight in Belgian psychiatry. ${ }^{30}$ Chlorpromazine had yet to prove itself in both Belgium and the Netherlands

\section{A helpful adjunct to local therapeutic biotopes}

Specia's special sales force enabled a growing group of Belgian and Dutch psychiatrists to test free samples of a drug advertised as a 'neuroplegicum' or 'neuroplégique' to achieve a wide spectrum of therapeutic effects-in almost any pathological condition from surgical stress to asthma, psychoses and toxicosis in newbornsby stabilizing the nerve system. ${ }^{31}$ These free samples were part of a unidirectional gift economy that had become an important part of the relationship between pharmaceutical companies and physicians. Thanks to a well-pitched combination of product innovation and promotion by nationally organized networks of pharmaceutical sales and scientific representatives, Specia Rhône-Poulenc had earned a reputation among Dutch and Belgian doctors by the early 1950 s.

Most psychiatrists would give chlorpromazine to their unruly patients to judge its qualities as an improved form of sleep therapy. Among others, Jean Bobon chose this testing trajectory in his private practice in Liège. Initially he insisted on the use of a cocktail of barbiturates and Largactil, as he was less enthousiastic about a Largactil monotherapy. Most psychiatrists in Belgium and the Netherlands shared the early perception of chlorpromazine (and later the Rauwolfia preparation reserpine (Serpasil ${ }^{\circledR}$ ), a cheaper alternative) as an adjunct instead of a cure. ${ }^{32}$

As far as the medical staff was concerned, the emphasis was on cautiously integrating chlorpromazine and reserpine into existing

\footnotetext{
${ }^{23}$ Bakker, Blok, \& Vijselaar (1999), p. 91, Pieters, Snelders, \& Houwaart (2006), p. 53.

24 Tolsma, Jedeloo, \& van Kemenade (1954), p. 1000.

25 Ibid.

26 Ibid.

27 Holtzer (1953)pp. 466-467, Boon (1955).

28 Anonymous (1953), p. 26.

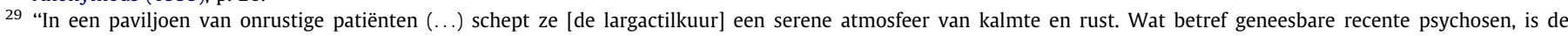
largactilkuur een kostbaar, snel werkend en gemakkelijk hanteerbaar hulpmiddel”, Jacobs (1954), p. 27.

30 Majerus (2010), pp. 63-64.

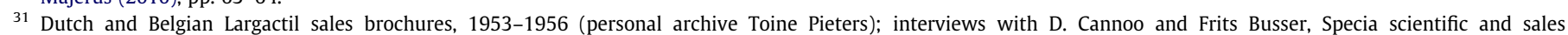
representatives, 7 and 10 September 2000.

32 Boon (1955), Rhijn van (1956), Evrard (1958).
} 
Table 1

Evolution of therapy at the Institut de Psychiatrie, Brugmann hospital, Brussels, from 1953 to 1957

\begin{tabular}{|c|c|c|c|c|c|}
\hline & $1953(n=18)$ & $1954(n=59)$ & $1955(n=52)$ & $1956(n=36)$ & $1957(n=36)$ \\
\hline ECT & $33 \%$ & $12 \%$ & $12 \%$ & $9 \%$ & $11 \%$ \\
\hline Chlorpromazine & $11 \%$ & $24 \%$ & $29 \%$ & $34 \%$ & $42 \%$ \\
\hline Insulin therapy & $17 \%$ & $15 \%$ & $2 \%$ & $0 \%$ & $3 \%$ \\
\hline Other drugs & $61 \%$ & $59 \%$ & $85 \%$ & $63 \%$ & $75 \%$ \\
\hline
\end{tabular}

therapeutic practices. ${ }^{33}$ Instead of immediately replacing conventional somatic treatments, such as shock and sleep therapy, the new drugs were welcomed as a valuable addition to the existing armoury of 'bodily cures' (see Table 1 ).

Each institution, asylum or hospital ward had a distinct method of testing and using chlorpromazine and/or reserpine. ${ }^{34}$ As a result, the dose and form of the drug in clinical use varied and depended on the local psychiatric 'biotope'. In this respect, chronologies were not national but local. The largest psychiatric hospital in Brussels, the Neuro-Psychiatric Titeca Center, did not use neurolepetics until $1956 .{ }^{35}$ Even inside the nine hospitals managed by the Brothers of Charity, various time frames existed describing when they began using chlorpromazine. At the end of 1953, only three out of the nine Charity hospitals used chlorpromazine. In the course of 1954 the rest of the Charity hospitals would follow. Chlorpromazine treatment gradually outpaced other somatic therapies. Exemplary is the total somatic therapy score for the year 1954 of all the Charity hospitals: 1 lobotomy, 116 insulin treatments, 354 electroconvulsive therapies, 13 treatments of malaria, 285 chlorpromazine (Largactil) therapies and 104 reserpine (Serpasil) therapies. ${ }^{36}$ This therapy list does not provide us, however, any information on the extent to which the various therapies were combined or not. It was quite common to combine electroshock therapy and chlorpromazine or chlorpromazine with barbiturates and promethazine (Phenergan) as part of a sleep therapy. ${ }^{37}$ But what this systematic record keeping, in this and other asylums in Belgium and the Netherlands, tells us is that unlike before, the psychiatrists started reporting on the nature and the effects of the new drug therapies at both the institute's and the individual patient level. ${ }^{38}$

Specia Rhône Poulenc anticipated the highly idiosyncratic daily medical practice of pharmacotherapy in Dutch and Belgian asylums and psychiatric clinics by promoting tailored forms of dosaging that would take into account the significant variation among individual patients. They managed differences by embracing the differences. Specia basically provided informational and technical support services by providing scientific information, general therapeutic guidelines and standard dosage forms (25/100mg tablets or suppositories, $25 / 50 \mathrm{mg}$ ampuls, $10 \mathrm{mg}$ powder and solution phials etc). ${ }^{39}$

Depending on the local culture of treatment and rehabilitation chlorpromazine or reserpine came to be regarded as either the most humane form of chemical restraint or as an important aid to existing social and psychotherapeutic treatment programs. However, it was not seen as a new form of chemotherapy for the mind, but rather as a state-of-the-art custom-tailored form of sedation. ${ }^{40}$ Chlorpromazine and reserpine were generally regarded as catalytic agents in a mental recovery process that opened up chronic schizophrenic patients to communication and social therapy. Most Dutch and Belgian psychiatrists believed that there was an essential interplay between the social climate of the setting in which the drug was provided and the effectiveness of the drug treatment. Tolsma would even go as far as to create a buddy system in his institution as a means to stimulate therapeutic optimism and to sustain chlorpromazine's favourable therapeutic effects. ${ }^{41}$

From the very beginning Belgian and Dutch doctors peppered their testimonies of the benefits of chlorpromazine with critical assessments of some of the problems associated with its use: from the social problems associated with the unexpected return of psychiatric patients to their families, to the high frequency of relapses and side effects. Despite the fact that no 'consistently serious' problems seemed to ensue from the use of the drug, doctors and nurses alike observed unwelcome side effects. In addition to allergic reactions, problematic distortions in patient blood values and sudden drops in blood pressure, as well as jaundice, fever and Parkinsonlike symptoms were recorded. They did not refrain from reporting these clinical problems-although there was little interaction between the Belgian and Dutch professionals-at the first international conference on chlorpromazine and neuroleptic drugs in Paris in October 1955. ${ }^{42}$

Most outspoken in his critical appraisal was Jacques de Busscher from the University of Ghent, who was also a psychoanalyst by training. In his opinion, the therapeutic effect was quite often due to the 'suggestive influence exerted by the offer of treatment' but the question was whether the principle of 'l'hibernation

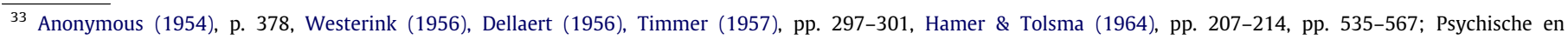
medicamenteuze behandelingsmethoden: 'Largactil', Verslagen der Provinciale Ziekenhuizen van Noord-Holland over het jaar $1955,1$.

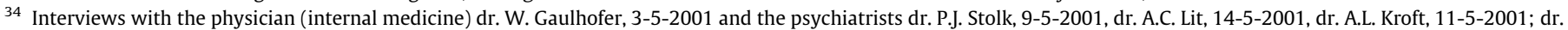
T.B. Kraft 7-5-2001; and dr. CH. Van Rhijn, 12-6-2001.

35 Missa (2006), p. 309.

36 B.D. (1955).

37 Westerink (1956), p. 121, Majerus (2010), p. 64.

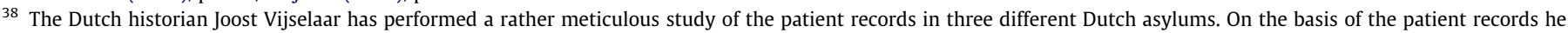

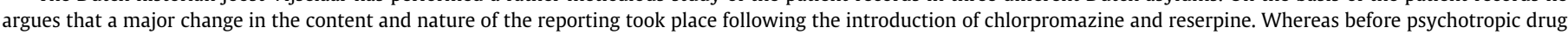

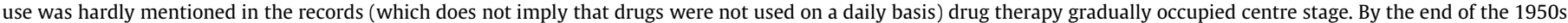
ninety percent of the patients would receive on a regular base one or the other or multiple chlorpromazine-like drugs; Vijselaar (2010), pp.196-198, pp. 340-341.

39 Anonymous (1961).

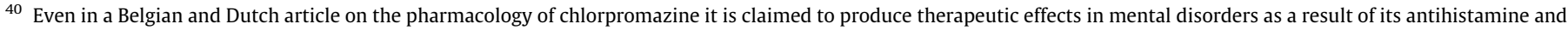

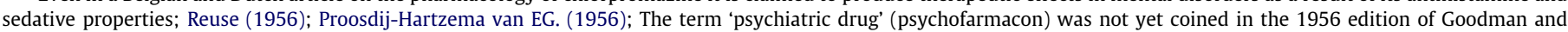

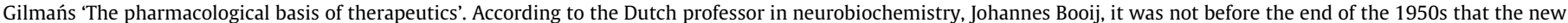
drugs in psychiatry became regarded as a separate pharmacotherapeutic group of substances; Booij J (1961), pp. 158-161.

41 Tolsma (1956), Rhijn (1960).

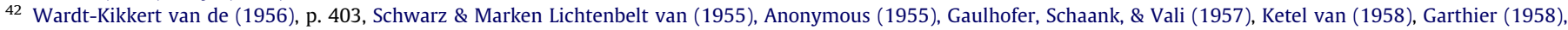
Fuldauer (1959), Rhijn van (1960), Booij (1961); W. Gaulhofer and H. van der Helm, 'Icterus veroorzaakt door chloorpromazine', Ibid. 105 (1961), $477-481$.
} 
artificielle', the basis of the therapeutic success of chlorpromazine, had too much of a 'Nazi-concentration' flavour to do good and no harm. ${ }^{43}$ However, this idea did not prevent Busscher from prescribing chlorpromazine and other drugs. The same was true for the Dutch guest of honour at the Paris conference, the head of the psychiatric department of the medical faculty at Utrecht University, Henricus Rümke. As a die-hard phenomenologist he hardly mentioned using drugs in his writings but as he indicated in his conference speech, chlorpromazine was welcomed as yet another pharmaceutical means to the end of therapeutically opening a patient's world of experience as a first step towards mental recovery. He shared this approach with Belgian's pioneer in developing outpatient services for young schizophrenics, René Dellaert from the University of Leuven. ${ }^{4}$

From the mid-fifties onwards, Specia Rhône Poulenc and Ciba began emphasizing the new qualities of chlorpromazine $\left(\right.$ Largactil $^{\circledR}$ ) and reserpine (Serpasil ${ }^{\circledR}$ ) and differentiating them from conventional sedatives as nicely reflected in the 1956/1957 drug ads. Whereas, Van Goghs painting The Round of the Prisoners was used to promote chlorpromazine's special relief-producing effect, the image of a pill superimposed on a brain with the caption 'different from the barbiturates' for reserpine, served to underline the new combination between sedation and mental recovery. ${ }^{45}$ In order to capture this new therapeutic profile and distinguish it from sedation, proper Dutch and Belgian psychiatrists began to label chlorpromazine and reserpine as neuroleptics and/or tranquillizers from 1956 onwards. ${ }^{46}$

\section{Towards new treatment concepts and the emerging problem of a Babel-like confusion}

Over time, the inclusion of chlorpromazine and reserpine in daily institutional drug menus manifested itself as changes in both treatment and nursing routines. The French procedure of providing chlorpromazine treatment in combination with bed nursing was simplified to drug therapy only. Subsequently, nurses, who had experienced difficulties administering unpleasant-tasting tablets and an aversion to managing an increasing number of pills, which often caused severe dermatological reactions, promoted a change to the use of orange-coated tablets from 1955 onwards. ${ }^{47}$ The nursing staff in the Endegeest mental hospital played a seminal role in the substitution of chlorpromazine tablets for the painful and necrosis-producing injections. ${ }^{48}$ The nursing staff in yet another Dutch mental hospital, Santpoort, initiated using wide-brimmed hats for patients taking chlorpromazine to protect their photosensitive skin against the sun. ${ }^{49}$ In addition, nurses had to schedule time to shave female patients who developed chlorpromazine-induced beards. Nurses also had to address the concerns of patients who did not use chlorpromazine but had opened up for communication and therapy and were terrorized by fellow patients. ${ }^{50}$ Moreover, using chlorpromazine and reserpine on a large scale required new monitoring procedures to check for the daily intake of the medication and to manage side effects.

The occasional severe side effects-extrapyramidal side effects (dyskinesias, restlessness, lip smacking movements and parkinsonian syndromes), jaundice and even fatal accidents-did not, however, prevent some psychiatrists from prescribing chlorpromazine in doses of up to 2000 milligrams daily (average adult dosage 200$400 \mathrm{mg}$ daily). ${ }^{51}$ On the contrary, in a number of Belgian and Dutch mental hospitals, psychiatrists began to use the neuromuscular reactions, closely resembling parkinsonism, induced by chlorpromazine in patients on higher dosages, as a clinical indicator of optimal treatment. ${ }^{52}$ Growing support for the idea of a relationship between psychiatric effects and neuromuscular side effects, helped increase the acceptance of targeted psychotropic agents. Moreover, this idea stimulated efforts to differentiate drugs like chlorpromazine from conventional sedatives by creating new categories of psychotropic drugs including: ganglioplegics, neuroplegics, ataractics, neuroleptics, analeptics, psycholeptics, psychoanaleptics, psychodysleptics, tranquillizers, and subsequently the terms minor and major tranquillizers. ${ }^{53}$ As French and Anglo-Saxon classifications for psychotropic drugs began to circulate, they were mixed and over time led to a Babel-like confusion in scientific communication as well as clinical communication. ${ }^{54}$

The Belgian and Dutch enthusiasm for chlorpromazine may not have been as hyperbolic as in the United States, but a cycle of promise, hope, therapeutic optimism, subsequent re-evaluation and disappointment was manifest. ${ }^{55}$ At the end of the $1950 \mathrm{~s}$ a growing number of reports were published in leading medical journals that assessed the long-term therapeutic benefits of the growing list of chlorpromazine-like drugs in asylum psychiatry. ${ }^{56}$ Initial enthusiasm made way for a critical reassessment of the effectiveness of chlorpromazine and reserpine. The Dutch psychiatrist, Henk van Andel, for instance, stated that despite the impressive improvements in the condition of chronic psychiatric patients, the new drug treatment programs had failed to lower the number of chronic patients in mental hospitals. On the basis of his experiences at the Dennenoord mental hospital, Van Andel claimed that this failure was due to the immense social and cultural gap between the worlds inside and outside the institutions. ${ }^{57}$ His colleague, Cees van Rhijn, who had studied the neuroleptic-related morbidity and mortality statistics at the Brinkgreve mental hospital, argued that this very gap contributed to a significant rise in suicides rates. ${ }^{58}$ In order to safeguard the longterm therapeutic benefits of neuroleptics, both psychiatrists made a strong plea for social reforms in mental hospitals and for establishing out-patient clinics with a strong focus on family-guided approaches to daily care.

A more radical voice could be heart from the director of the mental hospital in Zeist ('Het Christelijk Sanatorium'), Adriaan Lit. In comparing the symptoms of Parkinsonism with the neuromuscular side effects of the neuroleptics, he raised the question

\footnotetext{
43 De Busscher (1956).

44 Rümke, 1956, pp. 39-43, Dellaert (1956).

45 Series of Largactil adds dating from 1957 provided by doctor T. Schok; Medische Documentatie CIBA, no. 1 (1956) 3.

46 Proosdij-Hartzema van (1956), Schaepdrijver (1959).

47 Wardt-Kikkert van de (1956), Anonymous (1958).

48 Interview with Dr. Marianne van der Plas, 25 April 2001.

49 Interview with Dr. Thomas Bernard Kraft, 7 mei 2001.

50 Pieters et al. (2006), Blok (1997); Interview with the friar nurse Piet Rooijackers (Heiloo), 16 May 2001.

51 Praag Van (1966), pp. 47-52, Nijdam (1966), pp. 56-9, 122.

52 Paassen \& Ronner (1959). Anonymous (1960).

53 Wertenbroek (1960), Praag Van (1966), Nijdam (1966). Simonart (1961).

54 Majerus (2010), p. 69.

55 Swazey (1974).

56 Majerus (2010), p. 68.

57 Andel (1960).

58 Rhijn (1960).
} 
whether the new medical turn in psychiatry was just short of a chemical mask. However important and helpful in clinical terms, Lit argued that the neuroleptics on an individual patient basis had a rather general symptomatic and repressive effect that did not differ significantly from the conventional somatic interventions such as shock therapy, sleep therapy and leucotomy. ${ }^{59}$ Instead of a specific effect on the chemistry of the brain, he qualified the chemical effect of chlorpromazine and other neuroleptics as remarkably non-specific. Lit's rephrasing of the early French idea of a pharmacological leucotomy set the tone for a growing debate in the 1960s on the pros (e.g. 'chemical liberation') and cons ('chemical restraint') of psychotropic drug use in the treatment of mental disorders. ${ }^{60}$ Until the rise of the anti-psychiatry movement in the 1970s, however, the message of promise and hope of a new era of psychopharmacology would prevail. ${ }^{61}$

\section{Towards a new 'chemistry of the mind'}

It was the therapeutic and obvious commercial success of chlorpromazine that stimulated Specia Rhône Poulenc and rival manufacturers to develop analogues. By providing a pragmatic and measurable reference, the pharmacological activity of chlorpromazine began to serve as the point of comparison for analogue testing. Moreover, chlorpromazine was also regarded as the point of reference for determining the market price, as well as the health insurance reimbursement rate for the scores of phenothiazine neuroleptics or tranquillizers introduced on the medical market at the end of the 1950s and beginning of the 1960s. ${ }^{62}$

Belgian psychiatrists would experience the excitement of testing their own 'home-grown' neuroleptic haloperidol-developed and marketed by the newly established Janssen Pharmaceutica company in Beerse-which had a rather different chemical and pharmacological profile than chlorpromazine. At the university hospital of Liège, Jean Bobon would play a seminal role in showing that haloperidol was far more potent than chlorpromazine, less sedative and particularly useful for immediately calming down patients suffering from an acute and florid psychosis. ${ }^{63}$

On the basis of trial and error, doctors tried to find the appropriate dose and therapeutic response for the growing number of chlorpromazine-like drugs available, but this required increasing expertise to differentiate among the various compounds and to determine what drug combinations were therapeutically safe and helpful. ${ }^{64}$ The call for more therapeutic guidance, drug standards and laboratory controls became louder in scientific, medical and public quarters alike throughout the 1960s. ${ }^{65}$ Managing similarities and differences in patient responses was gradually pushed to the top of the research and clinical agenda. ${ }^{66}$

In the 1950s, what was still regarded as a significant part of the art of psychiatric doctoring, the materia medica preparation of tailored medication cocktails, became increasingly regarded as an outdated, unscientific and non-accountable practice by doctors, patients, regulators, pharmaceutical company and health insurance executives alike. In the wake of the thalidomide drug safety crisis all parties shared an interest in more consciously weighing the benefits, risks and costs of pharmacotherapeutic care by the means of creating drug standards. Polypharmacy was increasingly criticized for being irrational and irresponsive. In the process laboratory medicine-laboratory sites for monitoring drug effects proliferated in psychiatric hospitals-and epidemiology were making inroads into Belgian and Dutch psychiatry. ${ }^{67}$

A horizon, still described by the Dutch psychiatrist Johan Booij as 'pharmaco-psychiatry' in 1957, would become known as the 'chemistry of madness' by the mid 1960s. ${ }^{68}$ The observation that both chlorpromazine and reserpine counteracted the so-called psychosis induced by the hallucinogenic drug LSD stimulated a differentiation between the conventional hypnotics, sedatives and the new generation of neuroleptics and tranquillizers. ${ }^{69}$ By suggesting a relationship between chemical and clinical psychosis, this observation created a new scientific, medical and public horizon of brain chemistry and metric in vivo methods for psychopharmacology. LSD, the experimental tool par excellence and side-by-side with chlorpromazine, paved the way for a productive alliance between psychopathology and clinical epidemiology that would turn the so-called 'neurotransmitter revolution in medicine' into an addictive form of neurological mythology: the chemically transformable mind. ${ }^{70}$ The scientific debates in the field of psychopharmacology had the breath of a scientific spring with opportunities for both established scientists and young ambitious newcomers. This was exemplified by the proceedings of the Washington, DC CINP (Collegium Internationale Neuro-Psychopharmacologicum) meeting in $1966 .{ }^{71}$

At the conference dinner, Paul Janssen, the distinguished Belgian pharmacologist and entrepreneur, shared a table with the talented young Dutch chemist and pharmacologist, Jacques van Rossum. ${ }^{72}$ Van Rossum's earlier work on the relationship between chemical structure and biological activity had brought him into contact with Janssen, as he elaborated on Janssen's experimental animal model for testing potential neuroleptic compounds and their antagonism for amphetamine-induced behaviour. With the help of electrophysiological skills and technology acquired during a US Fulbright Fellowship, van Rossum built a state-of-the-art experimental system to measure (in a reproducible way) drug receptor interactions in various animal models-experimental manipulation of a receptor blockade electro-mechanical guidance system in animal tissue. ${ }^{73}$ Thus he was able to generate a series of reproducible data sets for possible mechanisms of amphetamine's psychomotor stimulant effects at the University of Nijmegen (the Netherlands) from the early sixties onwards. In the end, at the Washington, DC meeting, he outlined the hypothesis that neuroleptic drugs act by blocking

\footnotetext{
59 Lit (1959), p. 1296.

60 Sorgdrager (1958), Editorial (1961), Windt (1961), Regensburg (1961), Jong \& Kreutzkamp (1961).

61 Pieters \& Snelders (2009), p. 69.

62 Majerus (2010), p. 68

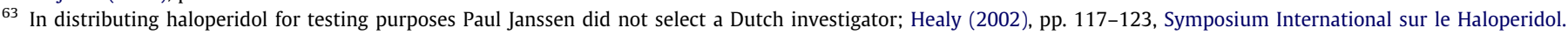
(1960).

${ }^{64}$ Fabius AJM. Jaarverslag Interne-afdeling over de jaren 1967-1968/1969-1970, Psychiatrisch Centrum St Willibrord, Heiloo, 1971.

65 Booij J. (1964).

${ }^{66}$ Nijdam (1966), Praag (1966), Pieters et al. (2006), p. 89.

67 Pieters et al. (2006), pp. 85-96.

68 Ibid.; Campbell (1971).

69 Booij (1957).

70 Healy (2002), pp. 106-109, Regan (2000), pp. 121-122, Solomon (2001), pp. 22-26.

71 Ban et al. (1998) pp. 23, 51.

72 Original dinner celebration photograph at the 5th CINP meeting March 28 1966, Sheraton Park Hotel, Washington D. C., Capitol Photo, 9822 k2.

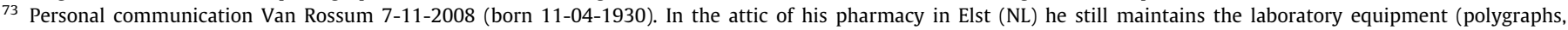
chromatographs etc) used in his research work in the 1960s and 1970s.
} 
dopamine receptors in the central nervous system..$^{74,75}$ Van Rossum even went so far as to argue that if this hypothesis could be further substantiated, it could have far-reaching consequences for the pathophysiology of schizophrenia. If so, then overstimulation of dopamine receptors might contribute to the aetiology of this crippling disease. Van Rossum added that an implication of the dopamine hypothesis was that the parkinsonoid side effects of neuroleptics could not be disconnected from their therapeutic action. Not surprisingly, this correlation was in agreement with the thinking of Janssen's close friend, German researcher Hans-Joachim Haase, who considered the parkinsonoid side effects as a condition sine qua non for determining the optimal therapeutic dose for a given test. Thus, Haase had developed a handwriting test for this purpose. ${ }^{76}$

Van Rossum's paper reflects a remarkable and, in hindsight, a somewhat naive unity in analytic perspective from an outsider to the field of neuropsychopharmacology. ${ }^{77}$ Van Rossum's rather mathematical and straightforward experimental and reductionist approach mirrored the systematic way Janssen preferred to tinker with molecule structures. In 1966 Janssen would propose his 'pharmacophore' concept of a hypothetical chemical structure shared by neuroleptic agents: the so-called chemical anatomy of neuroleptic drugs. ${ }^{78}$ This pharmacophore concept would contribute to the standardization of the screening for neuroleptic compounds.

The scientific community of neuropsychopharmacologists might have been less receptive to Van Rossum's and Janssen's conceptual ideas than hoped for, but this did not undermine their shared optimism that genuine progress was being made towards the understanding and treatment of mental disease and schizophrenia in particular. A second young Dutch scientific talent, psychiatrist and psychopharmacologist Herman van Praag, demonstrated a similar self-confidence at the 1966 CINP meeting. He had made a name for himself internationally by developing a structured standard interview for the recognition and registration of the vital depression symptom complex. ${ }^{79}$ This work was meant as a follow up to the Hamilton rating scale for depression. At the same time, he also showed an interest in neurochemistry with his work on the metabolism of depressed patients. ${ }^{80}$

At the time, all three men believed that international standardization of psychopharmacological research tools and of psychotropic drug treatments provided a means to the end for producing order out of disorder and of developing an evidence-based pharmaco-psychiatry. The research perspective and lexicon of the Dutch and Belgian scientists attending the Washington, DC conference in 1966, differed in major ways from those present at the Paris conference in 1955.

Whereas in 1955 the researchers involved were, in a large part, clinical researchers with a strong interest in evaluating the therapeutic effects of chlorpromazine, the 1966 group of psychopharmacologists were, for a large part, laboratory researchers with a strong focus on the molecular mechanisms of drug action. In their view the drug responses could and should be objectified by introducing reproducible laboratory measures in psychiatric practice.
For the exemplary representative of the 1955 group, the Dutch psychiatrist Tolsma, however, drug response depended not only on intrinsic, pharmacological properties of drugs but also on individual behaviour and environment. This was exemplified in 1968 by Tolsma's speech on the occasion of the 15th anniversary of the introduction of chlorpromazine in the Netherlands. The clinical pioneer Tolsma pointed out that as any improvement in psychiatric practice, new drug regimes were subject to a gradual process of 'habituation' in patients as well as for the medical and nursing staff. In his view the long-term use of neuroleptics was closely connected with a social tolerance reduction in mental hospitals. Tolsma was seriously concerned that what he had coined as 'a Copernican revolution in psychiatry' in 1956, was about to become bogged down in a continuation of the conventional practice of maintaining order and quiet. ${ }^{81}$

\section{Conclusion}

Tolsma's cri de coeur shows the ambivalence in the evaluation of the 1950s 'psychopharmacological revolution' that was still visible in 1968. And as we have shown, he had adequate historical reasons to doubt calling the introduction of the new drug regimes, a revolution in Dutch and Belgian psychiatry in the 1950s. As far as the daily treatment practices are concerned it seems more appropriate to speak in terms of evolution. Instead of a rather obvious departure from the past, we see an intriguing tango between old and new treatment features. Over time, as part of a trade-off between old and new (continuities and discontinuities), the successful newcomer helps to reconfigure the meanings and the uses of drug therapy as part of evolving treatment regimes in local therapeutic biotopes in Belgian and Dutch psychiatry. All these local biotopes learned to use chlorpromazine in their own specific ways and at their own pace. Doctors, nurses, patients and marketers all influenced the shifting routines, lexicons and logics surrounding the uses and understandings of chlorpromazine and its drug analogues. The marketers of Specia Rhône Poulenc strategically put Belgian and Dutch doctors in charge of producing their own therapeutic profiles of chlorpromazine as a remedy in the making. In doing so they successfully aligned the reductionistic laboratory approach of making drugs with the more holistic and tailored materia medica approach of prescribing drugs in the 1950s. In a historical perspective this leads to the rather important conclusion that chronologies were not national but local implying that for a better understanding of the historical development of psychiatric therapies, comparative studies of local practices are required.

As long as doctors, nurses, patients and the marketers of the pharmaceutical industry were able to narrow the margins of drug use and interpretation of individual disease conditions to workable levels by informal means, there was little incentive for more formalized standardization. The introduction of sugar-coated tablets, the incremental changes in the record keeping and nursing routines were the first products of informal and local standardization

\footnotetext{
74 Rossum (1967).

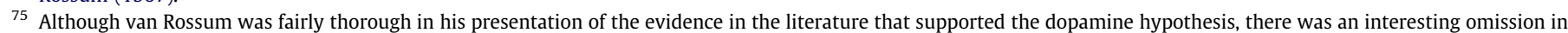

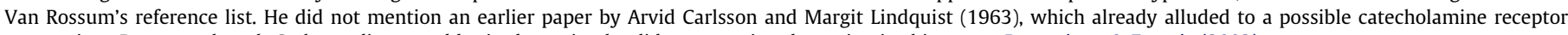
antagonism. But even though Carlsson discovered brain dopamine he did not mention dopamine in this paper. Baumeister \& Francis (2002).

${ }^{76}$ Haase (1961).

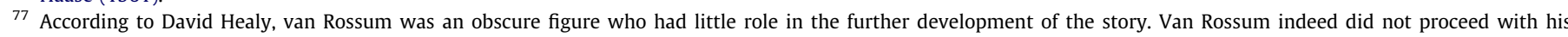

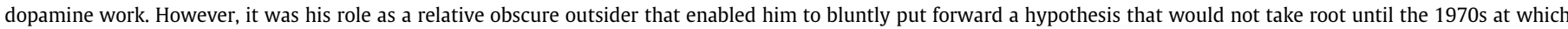

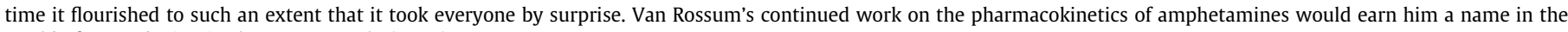
world of sport doping in the 1970s; Healy (2002), p. 207.

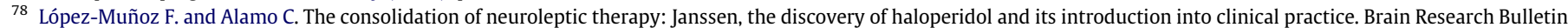
79 (2009), 130-141.

79 Praag, Uleman, \& Spitz (1965).

80 Praag (1967).

81 Tolsma (1968), p. 120.
} 
initiatives. The need for more formal and universal forms of standardization was nourished by changes in the supply and demand of psychotropic drugs in the course of the 1950s. Not until the highly idiosyncratic ways of using chlorpromazine and the fast growing number of therapeutic analogues began to show flaws (e.g., emerging practical problems of monitoring drug safety and effectiveness in growing numbers of patients and the increasing intrusion of interests from companies, governments, health insurance and the public), did a more general and permanent need for formal standardization become manifest in the 1960s.

As a new breed of Belgian and Dutch psychopharmacologists increasingly began to interfere with psychiatric research in the 1960 s, a gradual, but wholesale, transition of therapeutic reasoning and practice in psychiatry was already under way. This is exemplified by the changing nature and content of the record keeping in the psychiatric hospitals. Drug therapies moved centre-stage in the day-to-day treatment of psychiatric patients. Despite the fact that we point to continuities with earlier therapeutic developments in the 1950 s, there is no reason to contest the notion of a therapeutic revolution in the wake of the introduction of chlorpromazine and reserpine in Belgian and Dutch psychiatry. This revolutionary transition was not unlike the current shift to neuroscience and genomics in the field of psychiatry. From pragmatic medical and holistic phenomenological approaches in psychiatry there was a movement towards more standardized drug therapy based integrated medical and social approaches. The gradual acceptance of the "chemistry of the brain' neurotransmitter concepts would pave the way for the appropriation of new diagnostic and therapeutic vocabularies and concepts from the 1970s onwards.

\section{Acknowledgements}

This paper is a revised version of a talk prepared for the (European Science Foundation/Descartes Centre for the History and Philosophy of the sciences) workshop on standardizing psychoactive drugs and drug uses in the twentieth century at Utrecht University, The Netherlands, 23/24 April 2009. We are grateful to David Cohen, David Healy, Allan Horwitz and Stephen Snelders for their comments on that talk and the revised versions. We thank Julia Challinor for her help with the English version of this article.

\section{References}

Ackerknecht, E. H. (1959). A short history of psychiatry. New York: Hafner Anonymous (1953). De Largactil in de psychiatrie. Ziekenverpleging,, 175(October). Anonymous (1954). De betekenis van Largactil in de psychiatrie. Pharmaceutisch Weekblad, 89, 378.

Anonymous (1955). Afsluitings-icterus als gevolg van chloorpromazinegebruik Pharmaceutisch Weekblad, 90(1955), 634.

Anonymous (1958). Huidafwijkingen door chlorpromazine. Nederlands Tijdschrift voor Geneeskunde, 102, 2191.

Anonymous (1960). Discussion. Acta Neurologica et Psychiatrica Belgica (ANPB), 60, $146-147$.

Anonymous (1961). Het gebruik van largactil in de interne geneeskunde. Den Haag Specia: Handleiding voor de medicus practicus.

B.D. ('Alias of one of the friars of the Brothers of Charity') Bijzondere Aspecten van de Verpleging van onze Geesteszieken in 1954. Ziekenverpleging 186(August 1955), 8-14.

Bakker, C., Blok, G., \& Vijselaar, J. (1999). Delta. Negentig jaar psychiatrie aan de oude Maas. Utrecht: Trimbos.

Balz, V. (2010). Zwischen Wirkung und Erfahrung-Eine Geschichte der Psychopharmaca, Neuroleptica in der Bundesrepublik Deutschland 1950-1980. Bielefeld: Transcript.

T. A. Ban, D. Healy, E. Shorter (Eds.) (1998). The rise of psychopharmacology and the story of CINP. London: Animula.

Baumeister, A. A., \& Francis, J. L. (2002). Historical development of the dopamine hypothesis of schizophrenia. Journal of the History of the Neurosciences, 11, 265-277.

Blok, G. (1997). Onze kleine wereld. In J. Vijselaar (Ed.), Gesticht in de duinen (pp. 179-182). Hilversum: Verloren.

Booij, J. (1957). Farmaco-psychiatrie. Nederlands Tijdschrift voor Geneeskunde, 101, 1869-1872.
Booij, J. (1961). Zon en schaduw der psychofarmaca: "sudden falls" bij de behandeling met imipramine. Nederlands Tijdschrift voor Geneeskunde, 105 158-161.

Booij, J. (1964). De desillusie der psychopharmaca. Nederlands Tijdschrift voor Geneeskunde, 108, 1629-1636.

Boon, A. (1955). Largactil en verwante middelen in de psychiatrie en neurologie. Nederlands Tijdschrift voor Geneeskunde, 99, 2735-2741.

Campbell, R. (1971). The chemistry of madness. Life, 26(November), 66-86.

De Busscher, J. (1956). Impressions personelles sur les effects de l'atarax, de la chlorpromazine, de la reserpine et du AY 5406-1 (Parasan) en thérapeutiques psychiatrique. In J. Delay (Ed.), Colloque Internationalle sur la Chlorpromazine (pp. 707-723). G. Doin: Paris.

de Windt, E. (1961). Het bezwaar van psychopharmaca bij de ambulante patiënt. Nederlands Tijdschrift voor Geneeskunde, 105, 2515.

J. Delay (Ed.) (1956). Colloque Internationalle sur la Chlorpromazine et les medicaments neuroleptiques et thérapeutique psychiatrique. Paris: G. Doin.

Delay, J., Deniker, P., \& Harl, J. M. (1952a). Utilisation en thérapeutique psychiatrique d'une phénothiazine d'action centrale elective (4560 RP). Annales Médico-Psychologiques, 110, 112-113.

Delay, J., Deniker, P., \& Harl, J. M. (1952b). Traitement des états d'excitation et d'agitation par une méthode médicamenteuse derive de l'hibernothérapie. Annales Médico-Psychologiques, 110, 267-273.

Dellaert, R. (1956). De modernste chemopharmaca in de psychiatrie. Belgisch Tijdschrift voor Geneeskunde, 12, 6-10.

Deschamps, A. (1952). Hibernation artificielle en psychiatrie. La Presse Médicale, 60, 944-946.

Editorial (1961). Psychopharmaca. Nederlands Tijdschrift voor Geneeskunde, 105, 2217.

Evrard, A. (1958). Over het gebruik van reserpine in de psychiatrie. Belgische Tijdschrift voor Geneeskunde, 14, 787-788.

Fuldauer, M. (1959). Oogkrampen bij gebruik van reserpine. Nederlands Tijdschrift voor Geneeskunde, 103, 110.

Garthier, J. (1958). Extra-piramidale stoornissen bij het gebruik van chloorpromazine en reserpine. Nederlands Tijdschrift voor Geneeskunde, 102, 1982.

Gaulhofer, W., Schaank, J., \& Vali, A. (1957). Galactorroe veroorzaakt door chloorpromazine. Nederlands Tijdschrift voor Geneeskunde, 101, 264-266.

Gaulhofer, W., \& van der Helm, H. (1961). Icterus veroorzaakt door chloorpromazine. Nederlands Tijdschrift voor Geneeskunde, 105, 477-481.

Hamer, C., \& Tolsma, F. (1956). Algemeen Leerboek voor het verplegen van geestes en zenuwzieken. Leiden: Van Mantgem \& De Does.

Hamer, C., \& Tolsma, F. (1964). Algemeen Leerboek voor het verplegen van geestes en zenuwzieken. Leiden: Van Mantgem \& De Does.

Hamon, J., Paraire, J., \& Velluz, J. (1952). Remarques sur l'action du 4560 RP dans l'agitation maniaque. Annales Médico-Psychologiques, 110, 331-335.

Healy, D. (2002). The creation of psychopharmacology. Cambridge: Harvard University Press.

Holtzer, P. A. F. H. (1953). Studiereis naar Parijs ter kennismaking met het praeparaat "largactil" (4560 RP). Geneeskundige Gids, 23, 466-469.

Jacobs, R. (1954). Klinische Ervaring met Largactyl te Zelzate. Ziekenverpleging, 181(October 1954), 27.

Jong, de J. G. Y., \& Kreutzkamp, H. J. (1961). Psychopharmaca. Nederlands Tijdschrift voor Geneeskunde, 105, 2224-2229.

Laborit, H., Huguenard, P., \& Alluaume, R. (1952). Un nouveau stabilisateur végétatif (le 4560RP). La Presse Médicale, 60, 206-208.

Lit, A. C. (1959). De betekenis van het parkinsonoïd bij de behandeling met neuroleptica. Nederlands Tijdschrift voor Geneeskunde, 103, 1294-1296.

López-Muñoz, F., \& Alamo, C. (2009). The consolidation of neuroleptic therapy: Janssen, the discovery of haloperidol and its introduction into clinical practice. Brain Research Bulletin, 79, 130-141.

Majerus, B. (2010). Une stabilisation difficile. La chlorpromazine dans les années 1950 en Belgique. Gesnerus, 67, 57-72.

Missa, J. N. (2006). Naissance de la psychiatrie biologique: Histoire des traitements des maladies mentales au XXe siècle. Paris: Presses Universitaires de France.

Nijdam, S. J. (1966). Ervaringen met moderne psychofarmaca. Den Haag: Mouton \& Co.

Pieters, T. (2005). Interferon the science and selling of a miracle drug. New York: Routledge.

Pieters, T., \& Snelders, S. (2005). Mental ills and the 'hidden history' of drug treatment practices. In M. Gijswijt et al. (Eds.), Psychiatric cultures compared. Psychiatry and mental health care in the twentieth century: Comparisons and approaches (pp. 381-401). Amsterdam: Amsterdam University Press.

Pieters, T., \& Snelders, S. (2009). Psychotropic drug use: Between healing and enhancing the mind. Neuroethics, 2, 63-73.

Pieters, T., Snelders, S., \& Houwaart, E. (2006). De medicijn revolutie in de psychiatrie (1950-1985). Diemen: Veen Magazines.

Regan, C. (2000). Intoxicating minds. London: Orion.

Regensburg, A. C. (1961). Tranquilizers. Nederlands Tijdschrift voor Geneeskunde, 105, 2217-2224.

Reuse, J. J. (1956). Aspects de la pharmacodynamie des dérivés phenothiaziniques. In J. Delay (Ed.), Colloque International sur la chlorpromazine et les medicaments neuroleptiques en therapeutique psychiatrique (pp. 20-27). Paris: G. Doin.

Rümke, H. C. (1956). Quelques remarques concernant la pharmacologie et la psychiatrie. In J. Delay (Ed.), Colloque International sur la Chlorpromazine (pp. 39-43). Paris: G. Doin. 
Schaepdrijver, A. F. (1959). Over psychofarmacologie. Belgische Tijdschrift voor Geneeskunde, 15, 1132-1155.

Schim van der Loeff, H., \& Barnhoorn, J. (1947). Zielszieken en hunne verpleging. Roermond: JJ Romen \& Zonen.

Schwarz, F., \& van Marken Lichtenbelt, H. (1955). Icterus veroorzaakt door Largactil. Nederlands Tijdschrift voor Geneeskunde, 99, 3026-3031.

Scull, A. (1994). Somatic treatments and the historiography of psychiatry. History of Psychiatry, 5, 1-12.

Shorter, E. (1997). A history of psychiatry. New York: John Wiley.

Simonart, A. (1961). Essai de classification des psychotropiques. Revue Médicale de Louvain., 2, 147-152.

Solomon, A. (2001). The noonday demon: An atlas of depression. New York: Scribner.

Sorgdrager, P. (1958). Een proef met vijf "tranquilizers" bij psychoneurose. Pharmaceutisch Weekblad, 93, 733.

Swazey, J. P. (1974). Chlorpromazine in psychiatry: A study of therapeutic innovation. Cambridge (MA): MIT Press.

Symposium International sur le Haloperidol. (1960). Acta neurologica et Psychiatrica Belgica (ANPB) 60, 1-200.

Thuillier, J. (1999). Ten years that changed the face of mental illness. London: Martin Dunitz.

Timmer, A. (1957). Leerboek voor verplegenden van zenuwzieken en krankzinnigen. Haarlem: Erven F. Bohn.

Tolsma, F. J. (1956). Les neuroleptiques et le problème de ladaptation humaine. In J. Delay (Ed.), Colloque Internationalle sur la Chlorpromazine (pp. 41-49). Paris: G. Doin.

Tolsma, F. J. (1968). Largactil (chlorpromazine): Enkele herinneringen en feiten. Acta Psychopharmacologica Specia, 2(1968), 118-121.

Tolsma, F., Jedeloo, G., \& van Kemenade, J. (1954). De betekenis van 4560 R.P. (Largactil) in de psychiatrie. Nederlands Tijdschrift voor Geneeskunde, 98, 997-1001.

van Andel, H. (1960). Wijzigingen en verschuivingen in structuur en werkmethoden in de psychiatrische inrichting. Maandblad voor de Geestelijke Volksgezondheid, $15,5-14$.

van de Wardt-Kikkert, N. M. (1956). Quelques aspects de ĺapplication de la chlorpromazine dans un hôpital psychiatrique hollandais. In J. Delay (Ed.), Colloque Internationalle sur la Chlorpromazine (pp. 400-404). Paris: G. Doin.

van de Wardt-Kikkert, N. M., \& Rentmeester, J. (1953). Het largactil en zijn toepassing in de psychiatrie. Geneeskundige Gids, 24, 499-507. van Ketel, W., Morriën, J., \& Lenstra, H. (1958). Huidafwijkingen door chloorpromazine. Nederlands Tijdschrift voor Geneeskunde, 102, 1799-1804.

van Paassen, B., \& Ronner, H. J. (1959). Langdurige behandeling van geesteszieken met hoge doses fenothiazine. Nederlands Tijdschrift voor Geneeskunde, 103 2201-2203.

van Praag, H. M. (1966). Psychofarmaca: Een leidraad voor de praktiserend medicus. Assen: Van Gorcum.

van Praag, H. M. (1967). Some aspects of the metabolism of glucose and nonesterified fatty cids (NEFA) in depressed patients. In H. Brill (Ed.), Neuro-psychopharmacology. Proceedings of the fifth CINP congress (pp. 321-329). Amsterdam: Excerpta Medica Foundation.

van Praag, H. M., Uleman, A. M., \& Spitz, J. C. (1965). The vital syndrome interview: a structured standard interview for the recognition and registration of the vital depression symptom complex. Journal of Neurology, Neurochirurgy and Psychiatry, 68, 329-346.

van Proosdij-Hartzema, E. G. (1956). De farmacologie van chloorpromazine. Nederlands Tijdschrift voor Geneeskunde, 100, 833-842.

van Rhijn, C. H. (1956). De invloed van reserpine (Serpasil) op acute en chronische geestesziekten. Nederlands Tijdschrift voor Geneeskunde, 100, 1775-1790.

van Rhijn, C. H. (1960). Beschouwingen over de factoren, die het resultaat van de kuren met tranquillizers bepalen. Voordrachtenreeks, 2, 18-45.

van Rossum, J. M. (1967). The significance of dopamine-receptor blockade for the action of neuroleptic drugs. In H. Brill (Ed.), Neuro-psycho-pharmacology. Proceedings of the fifth CINP congress (pp. 321-329). Amsterdam: Excerpta Medica Foundation.

Vijselaar, J. (2010). Het Gesticht; Enkele reis of retour. Amsterdam: Boom.

von Haase, H. J. (1961). Extrapyramidal modification of fine movements-A "condition sine qua non" of the fundamental therapeutic action of neuroleptic drugs. In J. M. Bordelau (Ed.), Extrapyramidal system and neuroleptics (pp. 329-353). Montreal: Editions Psychiatriques.

Weber, M. (1999). Die Entwicklung der Psychopharmakologie im Zeitalter der naturwissenschaftlichen Medizin. Ideeengeschichte eines psychiatrischen Therapiesystems. München: Urban \& Vogel.

Wertenbroek, M. (1960). De klinische ervaringen met de nieuwere psychofarmaca Voordrachtenreeks van de Nederlandse Vereniging van Psychiaters in Dienstverband, 2, 3-17.

Westerink, D. (1956). De farmacologie en toepassing der fenothiazinederivaten. Pharmaceutisch Weekblad, 91, 113-144. 